\title{
Trophic role of planktonic rotifers in the Rhode River Estuary, spring - summer 1991
}

\author{
John R. Dolan*, Charles C. Gallegos \\ Smithsonian Environmental Research Center, PO Box 28, Edgewater, Maryland 21037, USA
}

\begin{abstract}
Rotifers were abundant (average ca 1000 ind. $\mathrm{l}^{-1}$ ) from March through September 1991 in a shallow, eutrophic subestuary of the Chesapeake Bay (USA). The rotifer community was usually dominated by Synchaeta cecilia with Brachionus plicatilis as the second most common species. Rotifer concentrations were negatively related to microflagellate abundances. However, reproductive output of $S$. cecilia, as measured by eggs female ${ }^{-1}$ or egg ratio (ER) followed temporal trends in microflagellate numbers. An inverse relationship between rotifers and herbivorous ciliates, which were dominated by a heterotrophic Strombidium sp., was apparent late spring through mid-summer, corresponding to a period of parallel abundance trends of auto- and heterotrophic microflagellates. Field experiments with natural plankton populations examining the removal of rotifers by copepods and sea nettles yielded clearance rate estimates of ca $50 \mathrm{ml}$ copepod $\mathrm{d}^{-1} \mathrm{~d}^{-1}$ and $20 \mathrm{l}$ sea nettle $\mathrm{e}^{-1} \mathrm{~d}^{-1}$. Calculations of predator removal rates and observations of shifts in ER with microflagellate concentration suggest that rotifer production is more likely food- than predator-limited in the Rhode River. Rotifer production figures, based on growth rates from ER data and grazing experiments, averaged ca $18 \mu \mathrm{g} \mathrm{C} \mathrm{l}^{-1} \mathrm{~d}^{-1}$, exceeding previous estimates of copepod production by an order of magnitude.
\end{abstract}

\section{INTRODUCTION}

Planktonic rotifers are thought to feed largely on algae of $\leq 20 \mu \mathrm{m}$ in size (Allan 1976, Pourriot 1977). While considered characteristic of freshwaters (Pennak 1978), they are known to occur in estuarine and marine waters and are apparently restricted to coastal areas due to high nutritional requirements (Heinbokel et al. 1988). However, beyond these generalities little is known of the importance of their ecological role in estuarine and marine systems, due largely to a lack of reliable quantitative data. Reports of rotifer population densities are almost exclusively based on plankton samples collected with nets of mesh size $\geq 44 \mu \mathrm{m}$ and often include little information on species composition (see Table 4, 'Discussion'). Based on the experiences of freshwater investigators, use of nets with mesh sizes $\geq 35 \mu \mathrm{m}$ can greatly underestimate rotifer abundance (Likens \& Gilbert 1970, Orcutt \& Pace 1984) and the underestimation is probably most serious with common, highly contractile, soft-bodied forms such as Synchaeta spp. Very few studies have employed sampling

\footnotetext{
- Present address: Station Zoologique, Ecologie du Plancton
} Marin, BP 28, F-06230 Villefranche-sur-Mer, France methods appropriate to these small metazoans. Furthermore, even when sampled adequately, forms such as Synchaeta spp. are easily overlooked in preserved samples if the rotifers were not anaesthetized prior to fixation to prevent their contraction into small, nondescript, ovoid masses. Despite these problems, rotifers have been found to be an important component of estuarine plankton communities. In Baltic systems they can rival ciliates in terms of biomass (Eriksson et al. 1977 ) and in some locales, exceed total protozoan biomass by a factor of 4 (Kivi 1986). Rotifer production can represent a significant portion of zooplankton production. For example, Johansson (1983) estimated that Synchaeta spp. represented about $20 \%$ of annual zooplankton production in a Swedish fjord and Allan et al. (1976) speculated that rotifer production might exceed copepod production by an order of magnitude in the Rhode River, a shallow eutrophic estuary. We have recently reported that rotifers, rather than ciliates or copepods, appear to be the dominant herbivores in a relatively simple planktonic food web during the fall in the Rhode River, Maryland, USA (Dolan \& Gallegos 1991).

In this paper we report on the abundance and composition of the rotifer fauna in the Rhode River for the 
spring and summer, a period in which trophic relationships appear more complex than during fall months (Dolan \& Gallegos 1991). We present evidence suggesting a close relationship between rotifers and herbivorous ciliates. We calculate production rates of Synchaeta cecilia, the dominant rotifer species, based on egg ratios and field experiments and also estimate removal rates due to grazing by copepods and sea nettles.

\section{METHODS AND MATERIALS}

Study site. The Rhode River estuary $\left(30^{\circ} 52^{\prime} \mathrm{N}, 76^{\circ}\right.$ $32^{\prime} \mathrm{W}$ ) is a shallow (mean depth ca $2 \mathrm{~m}$ ), well-mixed subestuary of the Chesapeake Bay with a tidal amplitude of ca $30 \mathrm{~cm}$ and has been the subject of a large number of studies (see Jordan et al. 1991, Gallegos et al. 1992 and ref. therein). It is eutrophic, exhibiting high chl a (ca $50 \mu \mathrm{g} \mathrm{l}^{-1}$ ) and nutrient concentrations (ammonium averages ca $4 \mu \mathrm{M}$ ) (Gallegos 1989).

Field sample collection and processing. Samples were collected from March 26 to September 13 at 1 to $7 \mathrm{~d}$ intervals (average interval $=2 \mathrm{~d}, \mathrm{SD}=1.5, \mathrm{n}=85$ ) during daylight hours at slack tide off the Smithsonian dock on the Rhode River. Sampling protocols followed the methods outlined in Dolan \& Gallegos (1991). Briefly, a $10 \mathrm{l}$ jug was immersed ca $10 \mathrm{~cm}$ below the surface; $20 \mathrm{ml}$ aliquots were preserved with glutaraldehyde for microflagellate and ciliate enumerations. For rotifers, $2 \mathrm{l}$ to $250 \mathrm{ml}$ aliquots, depending on density, were slowly concentrated over $20 \mu \mathrm{m}$ Nitex screen to $20 \mathrm{ml}$, carbonated water (soda water, carbonation method and salinity unknown) was added to inhibit contraction and after a few minutes the sample was fixed with glutaraldehyde. Microflagellates were enumerated following Haas (1982); $2 \mathrm{ml}$ subsamples were stained and 50 fields examined using a $100 \times$ objective. Ciliates were counted in whole water, rotifers in the $20 \mu \mathrm{m}$ concentrate, in settled samples using an inverted microscope.

Rotifers were identified following descriptions and figures of standard monographic works and keys (Remane 1929, Berzins 1952, Bjöklund 1972, RuttnerKolisko 1974, Voigt \& Koste 1978) as well as original species descriptions (Rousselet 1902, 1909, Smith 1904, Beauchamp 1907). Features of gross morphology, i.e. sizes and shapes of relaxed and contracted specimens, toe morphology and lorica morphology, were used in making taxonomic designations.

Eggs of Synchaeta cecilia populations were counted during 2 time periods when other rotifers, whose eggs could possibly be confused with $S$. cecilia, were not abundant (April 9 to May 11 and August 19 to September 12). This strategy was followed because $S$. cecilia eggs often disassociate with fixation in necessitating counting both attached and detached eggs, and the eggs of some other rotifer species could not be rapidly distinguished with confidence (e.g. S. fennica, whose eggs are apparently undescribed).

Ciliates were placed into guilds or trophic groups following the species and morphotype classifications outlined in Dolan (1991). An additional ciliate guild was distinguished, mixotrophic oligotrichs, consisting of species observed to contain chloroplasts based on the examination of glutaraldehyde-preserved material with epifluorescence at ca $500 \times$ total magnification. Only the abundances of aplastidic herbivorous ciliates [macrophagous in Dolan (1991)\} are reported here. Data on bacteriovorous, carnivorous, mixotrophic and autotrophic ciliates will appear elsewhere.

Temperature and salinity data were gathered from an automated sampling station, previously described (Cory \& Dressler 1981). Samples for chlorophyll were taken at approximately weekly intervals, as part of a separate study, and were processed following the protocol outlined in Gallegos (1989)

Predation experiments. Small-scale experiments were run to yield order of magnitude estimates of in situ predation rates. We employed the design of Frost (1972) in which clearance rates of grazers are calculated as prey disappearance rates in chambers with grazers, corrected for prey growth rates in chambers without grazers. Prey disappearance is assumed to equal grazer ingestion. The general approach in the copepod experiments was to monitor changes in rotifer concentrations in: (a) water gently passed through $280 \mu \mathrm{m}$ mesh Nitex to remove late stage copepods; and (b) the remaining water, effectively reverse filtered, with high copepod density.

A single 20 I sample of whole water was taken from the dock station. After mixing, water was slowly siphoned through a $25 \mathrm{~mm}$ diameter hose held inside a cylinder ( $75 \mathrm{~mm}$ diameter) fitted with a $280 \mu \mathrm{m}$ mesh Nitex bottom. The immersed end of the hose was kept $10 \mathrm{~cm}$ from the screen. The first $4 \mathrm{l}$ of siphoned water (free of late-stage copepods) was retained, gently mixed, and used to completely fill three $1 \mathrm{l}$ clear polycarbonate bottles. Siphoning was then continued until the 201 volume was reduced to 51 . This water, now containing 4 times the original concentration of latestage copepods, was gently mixed and used to fill completely 3 clear polycarbonate bottles. Two each of the screened (copepod-free) water bottles and the reverse filtered (copepod-concentrated) water bottles were placed in situ (about $20 \mathrm{~cm}$ below the surface) for incubation, in a clear bucket, filled with water suspended from a floating portion of the dock. The 2 remaining samples were processed for time zero $\left(t_{0}\right)$ determinations of rotifer concentrations. The incubated 
bottles were retrieved and processed for rotifer and copepod enumerations after ca $20 \mathrm{~h}$. All experimental parameters were calculated employing the system of equations devised by Frost (1972). Copepod grazing parameters were calculated based on the abundance of late-stage (size $\geq 750 \mu \mathrm{m}$ long) copepods, all of which were Acartia sp. An average prey growth rate, from the 2 copepod-free bottles, was used to calculate individual grazing parameters for the 2 grazer (concentrated copepod) bottles. Experiments were run on July 25, 31 and August 8,1991; all incubations began at ca 10:00 h local time.

Grazing experiments with sea nettles employed a slightly different design. Five clear polycarbonate buckets $(20$ l) were filled with water and suspended from a floating dock. A single sea nettle Chrysara quinquecirrha, ca $75 \mathrm{~mm}$ bell diameter, was placed into each of 2 to 3 buckets. For each of the buckets 11 samples were removed at $t_{0}$ and after $20 \mathrm{~h}$ incubation. Rates of prey growth were calculated separately for each control (i.e. buckets without sea nettle added). The average prey growth rate in the controls was used in calculating clearance and ingestion rates for the individual sea nettles. Water in the control containers was not screened to remove copepods but none were found in samples examined for rotifer enumerations.

Sea nettle egestion experiments. To determine if natural populations of sea nettles had consumed rotifers, an experiment, similar to that of Purcell et al. (1991), was run to monitor the egestion of recognizable rotifer remains. Rotifer-free water (20 l) was prepared by slowly siphoning water through a $20 \mu \mathrm{m}$ screen. The water was then dispensed into 21 containers (10 total). A single sea nettle (ca $75 \mathrm{~mm}$ bell diameter), scooped out of the surface water at the dock using a cylinder fitted with a $280 \mu \mathrm{m}$ mesh bottom, was put into each container. The containers were placed in an incubator at $26^{\circ} \mathrm{C}$ (ambient water temperature was $27^{\circ} \mathrm{C}$ ). Two or 3 containers were processed at hourly intervals for 4 h. The sea nettle was removed by pouring the water through the $280 \mu \mathrm{m}$ screen and the water was then filtered through a $20 \mu \mathrm{m}$ mesh Nitex screen and the concentrate settled and then examined using an inverted microscope. Only empty lorica of Brachionus plicatilis were enumerated, no other rotifer remains were recognizable.

Rotifer production. Production of Synchaeta cecilia was estimated using abundance figures from field samples, a biomass conversion factor $(0.0168 \mu \mathrm{g} \mathrm{C}$ S. cecilia ${ }^{-1}$ ) from the literature (Heinbokel et al. 1988), and growth rates derived from 2 different methods. For the 5 dates on which grazing experiments were run, growth rates from the control chambers were used. For the 2 extended periods in spring and summer when egg numbers for S.cecilia were determined (see above), the egg ratio method was used.

The egg ratio method, originally developed for rotifers by Edmondson $(1960,1965)$ allows calculation of birth rates given knowledge of the egg development time (EDT) and the average number of eggs per female, the egg ratio (ER). ER was determined by microscopic examination and EDT was calculated using the equation of Heinbokel et al. (1988) relating incubation temperature (in situ water temperature, $T$ in ${ }^{\circ} \mathrm{C}$ ) to EDT for Synchaeta cecilia:

$$
\log \mathrm{EDT}=1.77+0.557(\log T)-0.902(\log T)^{2}
$$

Birth-specific reproductive rate, $b\left(\mathrm{~h}^{-1}\right)$, was calculated following Paloheimo (1974):

$$
b=\ln (1+\mathrm{ER}) / \mathrm{EDT}
$$

Calculating production from birth rates and biomass assumes that all eggs reach adult size.

The accuracy of estimating production rates using ER was assessed by comparing changes in Synchaeta cecilia concentrations in water samples incubated for $24 \mathrm{~h}$ with a calculated birth rate based on ER. On August 12 a single $20 \mathrm{l}$ sample of whole water was obtained from the dock at a typical sampling time $(10: 00 \mathrm{~h})$. After thorough gentle mixing, a time zero sample of 21 was withdrawn and processed for abundance and ER estimates. Replicate 1.51 samples (5) were incubated at $24{ }^{\circ} \mathrm{C}$ for $24 \mathrm{~h}$ and processed for estimates of rotifer concentration and ER.

\section{RESULTS}

\section{Field sample data}

Nine rotifer species were encountered with Synchaeta cecilia and Brachionus plicatilis generally dominating in abundance (Fig. 1A, B). In descending order of numerical abundance, the other species were: S. baltica, Proalides tentaculatus, S. fennica, S. baltica, Brachionus sp., $S$. vorax, Notholca acuminata and Trichocerca marina. Generally, neither the gradual increases in temperature (from 11 to $30^{\circ} \mathrm{C}$ ) and salinity (from 7.5 to $12 \mathrm{ppt}$ ) nor marked variations in chl a

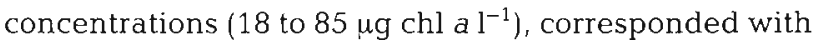
obvious changes in rotifer abundance or the species assemblage (Fig. 1C). A singular exception was the occurrence of $P$. tentaculatus which appeared to coincide with dinoflagellate blooms (based on casual observations), although dinoflagellate remains were not detectable in any of the specimens examined.

Temporal changes in total rotifer concentrations (Fig. 2) did not parallel shifts in microflagellate numbers nor did the 2 groups show an inverse relationship. However, an inverse relationship between total rotifers 

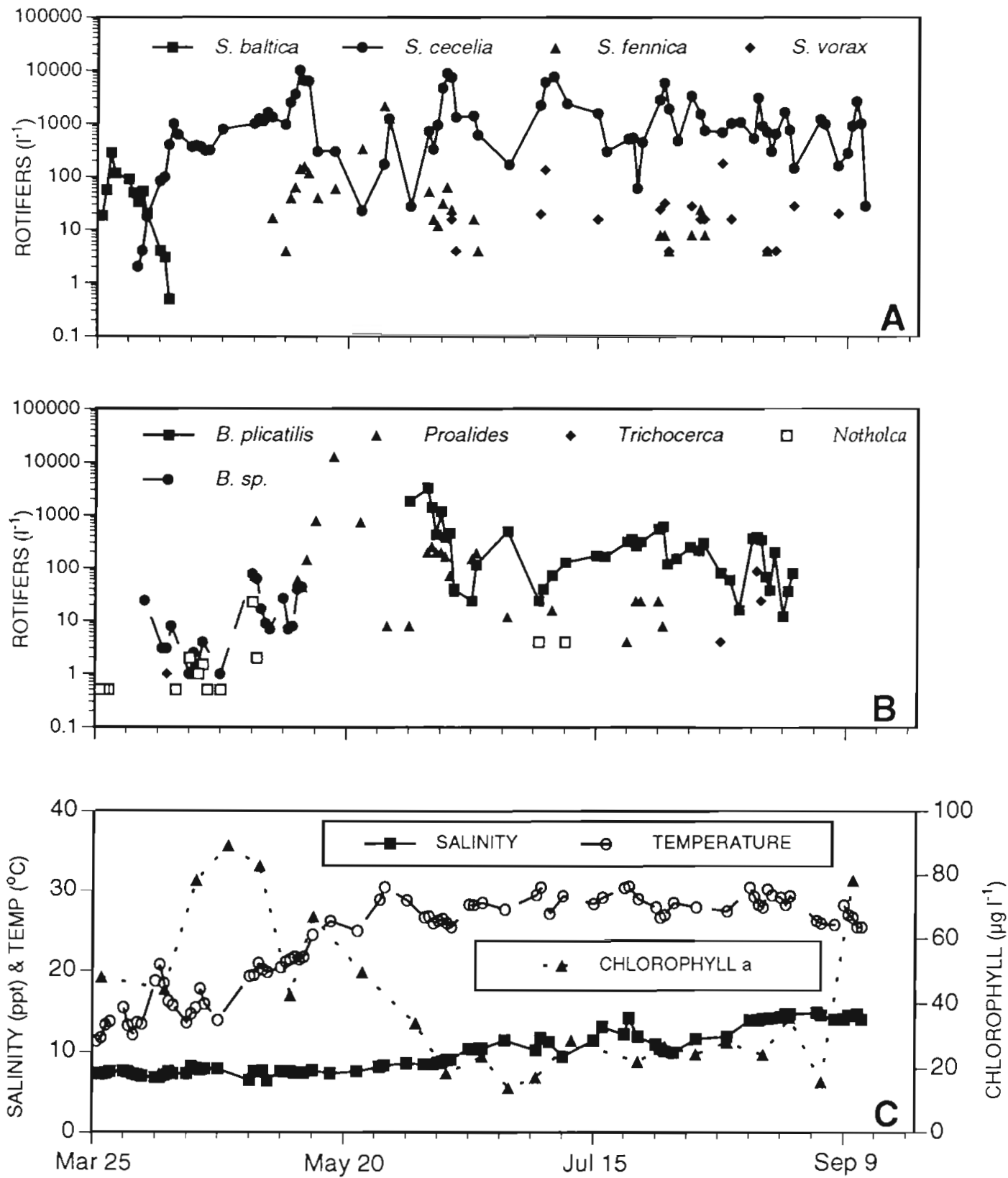

Fig. 1. Temporal abundances of (A) Synchaeta spp., (B) Brachionus spp. and other rotifers, and (C) temporal changes in salinity, temperature, and chl a concentrations in the Rhode River estuary

and herbivorous ciliates was apparent (Fig. 2A). Herbivorous ciliates were usually dominated numerically by a medium-sized ( $40 \mu \mathrm{m}$ diameter) Strombidium sp. Occasionally tintinids were abundant, Tintinnopsis spp. and Eutintinnus spp., especially when oligotrich concentrations were low.

The inverse rotifer-herbivorous ciliate relationship was most obvious from early May through August when abundance trends of autotrophic and heterotrophic microflagellates closely paralleled each other.
The parallel abundance pattern of the 2 microflagellate groups (Fig. 2B), which are ostensibly distinct trophically, suggests common regulation - presumably via predation.

Considerable variation was seen in the Synchaeta cecilia ER during both spring and summer. Changes in ER appeared to track changes in microflagellate concentration (Fig. 3).

Results of linear correlation analysis are given in Table 1. Synchaeta cecilia ER was positively correlated 

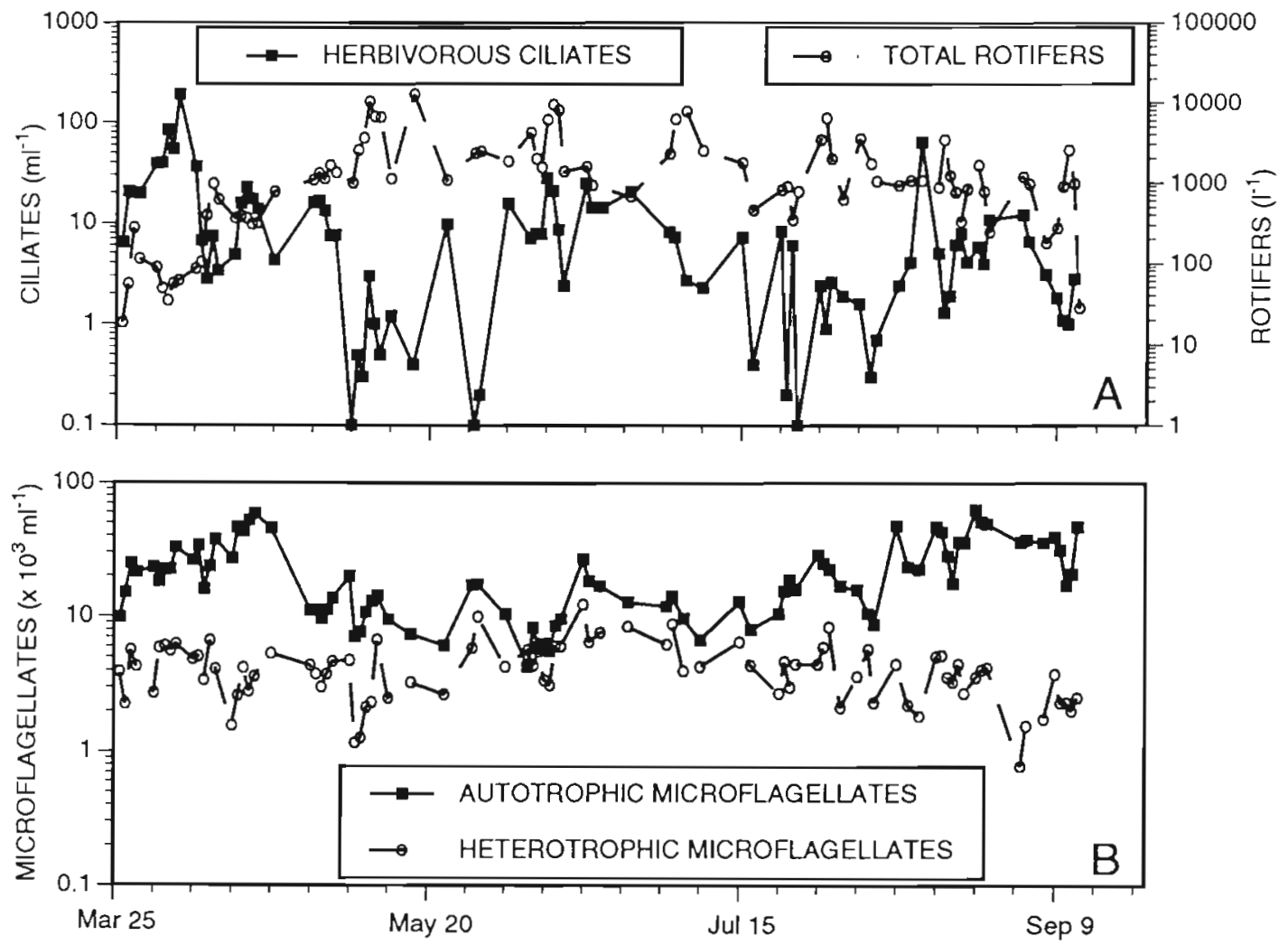

Fig. 2. (A) Concentrations of herbivorous ciliates and total rotifers. (B) Abundances of autotrophic (chloroplast-containing) and heterotrophic (aplastidic) microflagellates

with flagellate concentration. In contrast, the abundance of $S$. cecilia was negatively correlated with flagellate and herbivorous ciliate concentrations. Total rotifer abundance was also negatively related to microflagellate as well as herbivorous ciliate abundance.

\section{Predation experiments}

Copepods appeared to clear water of Synchaeta cecilia at higher rates ( 44 and $57 \mathrm{ml}$ copepod ${ }^{-1} \mathrm{~d}^{-1}$ ) than of Brachionus plicatilis (29 and $20 \mathrm{ml} \mathrm{copepod}^{-1}$ $\mathrm{d}^{-1}$ ), although the rates were only significantly different in the August experiment (Table 2). Growth rates of the 2 rotifer species were of similar magnitude in the experiments but with $B$. plicatilis showing higher rates $\left(0.042\right.$ to $\left.0.060 \mathrm{~h}^{-1}\right)$ than S. cecilia $\left(0.021\right.$ to $\left.0.048 \mathrm{~h}^{-1}\right)$.

Experiments with sea nettles, in contrast to the copepod experiments, showed higher clearance rates on Brachionus plicatilis than on Synchaeta cecilia (Table 2). But few replicates and high variances precluded demonstration of significant difference. For the 2 experiments, mean clearance rates on $S$. cecilia were 13.8 and $6.4 \mathrm{l}$ sea nettle ${ }^{-1} \mathrm{~d}^{-1}$ compared to 28.3 and 41.2 l sea nettle $e^{-1} \mathrm{~d}^{-1}$ for clearance of $B$. plicatilis (Table 3)

\section{Sea nettle egestion experiment}

Egested Brachionus plicatilis were easily distinguished from recently or long dead animals. Loricas were either completely empty and perforated with many small holes or contained only a small (30 $\mu \mathrm{m}$ diameter) brown bolus of material near the center of the lorica. B. plicatilis loricas were egested at ca $10 \mathrm{~h}^{-1}$ (Fig. 4). Assuming steady-state conditions by equating egestion to ingestion, and given a prey concentration of 36 B. plicatilis $\mathrm{l}^{-1}$ (based on a sample from the experimental date), yields a clearance rate estimate of 6.61 sea nettle $\mathrm{e}^{-1} \mathrm{~d}^{-1}$. This rate, while not significantly different, is lower than the rates of 28.3 and 41.2 estimated from the grazing experiments which monitored rotifer disappearance rates

\section{Production estimates}

The egg ratio method gave a similar but slightly higher estimate of population growth than that calculated from increases in rotifer concentrations in incubated water samples. The mean ER at $t_{0}(0.221)$ was statistically indistinguishable from the $24 \mathrm{~h} \mathrm{ER}, 0.192$ $(S D=0.0366)$. Based on the time zero $E R$, the predicted 


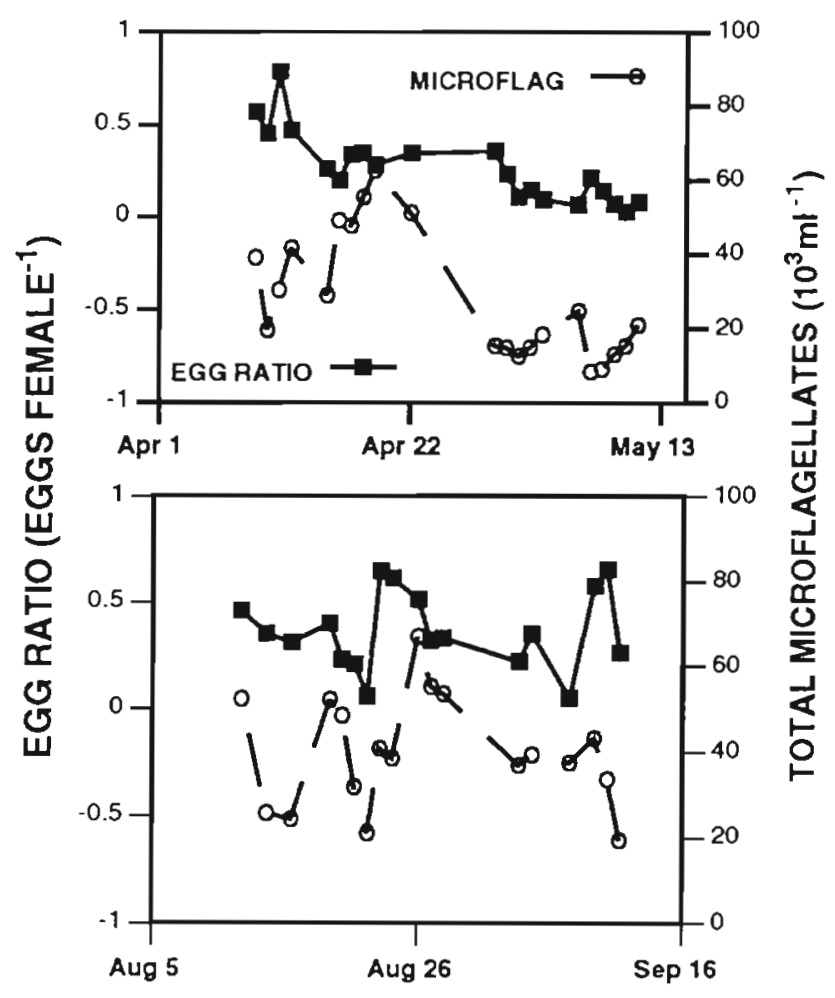

Fig. 3. Synchaeta cecilia. Reproductive effort as measured by eggs female ${ }^{-1}$ and food supply considered as microflagellate concentration

mean abundance in the incubated samples after $24 \mathrm{~h}$, assuming no death, was 2360 ind. $1^{-1}$ compared to an actual value of 2079 ind. $l^{-1}(S D=29.7)$.

Production estimates using the egg ratio method ranged from 1.9 to $48.2 \mu \mathrm{g} \mathrm{Cl}^{-1} \mathrm{~d}^{-1}$ during the spring and 0.5 to $57.4 \mu \mathrm{g} \mathrm{C}^{-1} \mathrm{~d}^{-1}$ during the summer. Estimates based on growth rates obtained in the control treatments of grazing experiments (late summer)

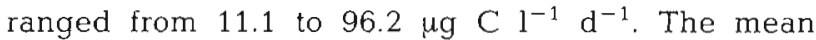
production rate was $18.3 \mu \mathrm{g} \mathrm{Cl}^{-1} \mathrm{~d}^{-1}(\mathrm{SD}=19.7)$ based on both ER and grazing experiment data. Production
Table 1. Results of correlation analysis $\left(Y_{1}\right.$ with $\left.Y_{2}\right)$. Organism concentrations (rotifers, herbivorous ciliates, total microflagellates and autotrophic microflagellates) were square root transformed. T flag: total microflagellates; A flag: autotrophic microflagellates; $\mathrm{H}$ cil: herbivorous ciliates

\begin{tabular}{|c|c|c|c|}
\hline$Y_{1}$ & $Y_{2}$ & $\mathrm{r}$ & $\mathrm{n}$ \\
\hline Synchaeta cecilia abundance & $\begin{array}{l}\text { T flag } \\
\text { A flag } \\
\text { H cil }\end{array}$ & $\begin{array}{l}-0.4623 \cdots \\
-0.3325^{\circ} \\
-0.27166^{\circ}\end{array}$ & $\begin{array}{l}75 \\
75 \\
75\end{array}$ \\
\hline Synchaeta cecilia egg ratio & $\begin{array}{l}\text { T flag } \\
\text { A flag } \\
\text { H cil }\end{array}$ & $\begin{array}{l}0.3714^{\circ} \\
0.4478^{\circ} \\
0.0928^{\circ}\end{array}$ & $\begin{array}{l}39 \\
39 \\
39\end{array}$ \\
\hline Synchaeta cecilia production & $\begin{array}{l}\text { T flag } \\
\text { A flag } \\
\text { H cil }\end{array}$ & $\begin{array}{l}-0.0491 \\
-0.0215 \\
-0.2885\end{array}$ & $\begin{array}{l}39 \\
39 \\
39\end{array}$ \\
\hline Total rotifer abundance & $\begin{array}{l}\text { T flag } \\
\text { A flag } \\
\mathrm{H} \text { cil } \\
\text { Chl a }\end{array}$ & $\begin{array}{l}-0.4370 \cdots \\
-0.4562 \cdots \\
-0.3661 \cdots \\
-0.328\end{array}$ & $\begin{array}{l}85 \\
85 \\
85 \\
16\end{array}$ \\
\hline Herbivorous ciliate abundance & $\begin{array}{l}\text { T flag } \\
\text { A flag } \\
\text { Chl a }\end{array}$ & $\begin{array}{l}0.1883 \\
0.131 \\
0.288\end{array}$ & $\begin{array}{l}85 \\
85 \\
17\end{array}$ \\
\hline
\end{tabular}

rates followed trends in flagellate concentration qualitatively, but not quantitatively (Fig. 5, Table 1).

\section{DISCUSSION}

\section{Rotifer community composition}

Rotifers in the Rhode River during the spring and summer were dominated by Synchaeta and Brachionus species and averaged ca 1000 ind. $\mathrm{I}^{-1}$. Most brackish water systems are dominated by Synchaeta spp. but abundances seem to range widely among systems (Table 4). However, it should be noted that low concentrations have been reported based on large $(\geq 50 \mu \mathrm{m})$

Table 2. Synchaeta cecilia, Brachionus plicatilis. Summary of copepod grazing experiment results. to: time zero prey concentration in ind $\mathrm{ml}^{-1} ; K=$ prey growth constant in the absence of grazers; $[\mathrm{C}]=$ time-averaged prey concentration (ml ${ }^{-1}$ ) to which the grazers were exposed; $F=$ filtration or clearance rate, apparent volume swept clear of prey in $\mathrm{ml} \mathrm{grazer}^{-1} \mathrm{~d}^{-1} ; I=\mathrm{calculated}$ grazer ingestion rate in organisms consumed $\mathrm{d}^{-1}$; ND: no copepods present during the July 31 experiment. Parameters are given $\pm \mathrm{SD}$ of the replicates

\begin{tabular}{|llccccc|}
\hline Date & \multicolumn{1}{c}{ Prey } & $t_{0}$ conc & $K\left(\mathrm{~h}^{-1}\right)$ & IC] & $F$ & $I$ \\
\hline July 25 & S. cecilia & 0.46 & $0.021 \pm 0.016$ & $0.16 \pm 0.13$ & $44 \pm 11.2$ & $6.9 \pm 1.3$ \\
& B. plicatilis & 0.34 & $0.055 \pm 0.006$ & $0.19 \pm 0.02$ & $29 \pm 4.8$ & $5.6 \pm 1.0$ \\
July 31 & S. cecilia & 1.14 & $0.048 \pm 0.000$ & ND & ND & ND \\
& B. plicatilis & 0.29 & $0.060 \pm 0.008$ & ND & ND & ND \\
August 8 & S. cecilia & 0.61 & $0.041 \pm 0.033$ & $0.33 \pm 62.7$ & $57 \pm 11.9$ & $18.5 \pm 0.4$ \\
& B. plicatilis & 0.21 & $0.042 \pm 0.007$ & $0.12 \pm 14.7$ & $20 \pm 3.9$ & $4.2 \pm 0.5$ \\
& & & & & & \\
\end{tabular}


Table 3. Synchaeta cecilia, Brachionus plicatilis. Summary of sea nettle grazing experiments results. Parameter abbreviations and units as in Table 1

\begin{tabular}{|llcccrr|}
\hline Date & Prey & $t_{0}$ conc & $K\left(\mathrm{~h}^{-1}\right)$ & {$[\mathrm{C}]$} & $F$ & $I$ \\
\hline August 5 & S. cecilia & $2.14 \pm 1.10$ & $0.041 \pm 0.004$ & $2.449 \pm 0.57$ & $13842 \pm 11801$ & $30426 \pm 20950$ \\
& B. plicatilis & $0.30 \pm 0.09$ & $0.059 \pm 0.006$ & $0.237 \pm 0.03$ & $41167 \pm 11347$ & $9910 \pm 3735$ \\
August 12 & S. cecilia & $0.40 \pm 0.09$ & $0.021 \pm 0.002$ & $0.49 \pm 0.08$ & $6354 \pm 5951$ & $2887 \pm 2415$ \\
& B. plicatilis & $0.06 \pm 0.01$ & $0.051 \pm 0.009$ & $0.06 \pm 0.07$ & $28279 \pm 2904$ & $1564 \pm$ \\
& & & & & & \\
\hline
\end{tabular}

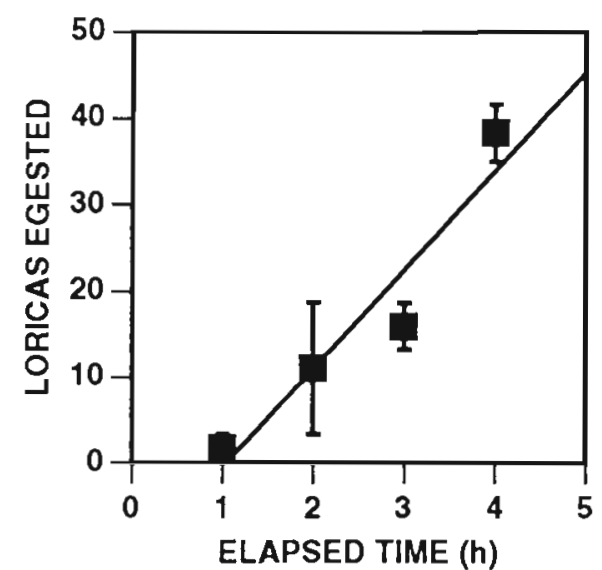

Fig. 4. Brachionus plicatilis. Egestion of rotifer remains in a wild population of Chrysaora quinquecirrha. Estimates of average numbers ( $\pm \mathrm{SE}$ ) of $B$. plicatilis loricas egested vs time, based on the appearance of loricas in containers of $20 \mu \mathrm{m}$ screened water with single sea nettles

mesh net samples (Fig. 6), resulting in likely underestimation of small or soft-bodied rotifer concentrations.

We do not know if the rotifer community we found is typical for the spring - summer season. However, 1991 data conform in certain respects to previous work in this system. Based on samples taken over a year with an $80 \mu \mathrm{m}$ mesh net, Allan et al. (1976) described rotifers as abundant, ranging from 1 to 2500 ind. $1^{-1}$ from late October to late May and appearing again briefly in July; Brachionus plicatilis was the most common species. The differences between the data of Allan et al. (1976) and ours could represent the results of a longterm trend toward eutrophication in the Rhode River (Correll 1981), inter-annual differences, or simply sampling methods. As noted above, Synchaeta spp. were probably underestimated in the $80 \mu \mathrm{m}$ net samples of Allan et al. (1976). Recently, we reported that during fall months a Synchaeta sp. (now identified as $S$. cecilia), present at an average concentration of about 700 ind. $1^{-1}$, dominated the rotifer community (Dolan \& Gallegos 1991).

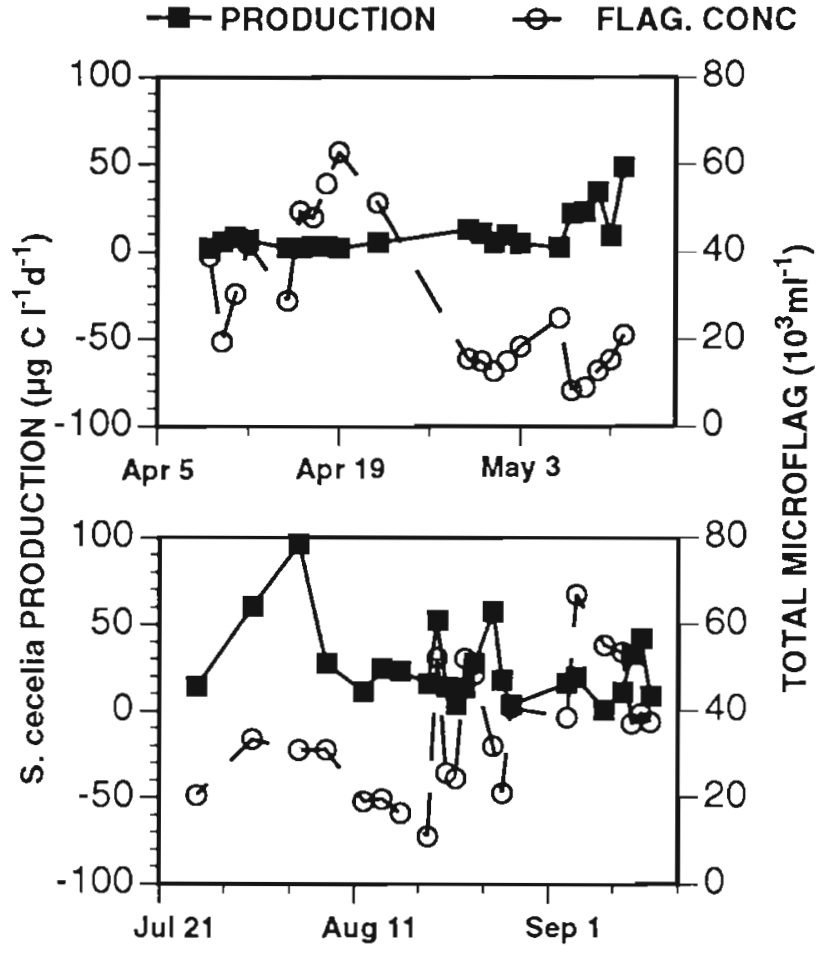

Fig. 5. Synchaeta cecilia. Production in the Rhode River estuary based on population growth rates estimated from egg ratio data and grazing experiments

\section{Regulation of rotifers}

The dominant rotifers (Synchaeta and Brachionus) found in the Rhode River are commonly considered as exploiters of small prey, as the same or similar species have been either cultured or found to feed readily on microflagellate prey (Synchaeta: Pourriot 1965, Blackbourn 1974, Stemberger \& Gilbert 1985, Egloff 1988; Brachionus: Doohan 1973, Dewey 1976, Pilarska 1977. Pourriot \& Rougier 1979, Walker 1981, Yúfera \& Pascual 1985, Scmid-Araya 1991). In work conducted in the fall in the Rhode River, rotifers and microflagellates showed inverse oscillations; rotifer abundance was successfully modeled as a function of microflagellate density (Dolan \& Gallegos 1991). Data presented here 
Table 4. Comparison of maximum reported rotifer densities in estuarine systems. Studies employed a wide variety of sampling strategies, and generally reported concentrations integrated over the water column or through the surface layer

\begin{tabular}{|c|c|c|c|c|c|}
\hline Study site & Taxa & $\begin{array}{c}\text { Conc. } \\
\left(1^{-1}\right)\end{array}$ & Month & $\begin{array}{c}\text { Net size } \\
\quad(\mu \mathrm{m})\end{array}$ & Source \\
\hline Potomac River, USA & Synchaeta cecilia & 4000 & Mar & 35 & Hienbokel et al. (1988) \\
\hline Chesapeake Bay, USA & Rotifers & 500 & Nov & 44 & Brownlee \& Jacobs (1987) \\
\hline Rhode River, USA & Brachionus & 2500 & Apr & 80 & Allen et al. (1976) \\
\hline Rhode River, USA & Synchaeta sp. & 6000 & Nov & 20 & Dolan \& Gallegos (1991) \\
\hline Patuxent River, USA & S. baltica & 1000 & Dec & 50 & Sellner et al. (1991) \\
\hline Damariscota River, USA & Synchaeta spp. & $50-100$ & May & $W W^{a}$ & Sanders (1987) \\
\hline Narragansett Bay, USA & Rotifers & 22 & Apr & 153 & Hulsizer (1976) \\
\hline San Francisco Bay, USA & Synchaeta spp. & 10 & May & 64 & Ambler et al. (1985) \\
\hline Bothnian Sea, Sweden & Synchaeta spp. & 0.5 & Aug & 160 & Eriksson (1973) \\
\hline Bothnian Sea, Sweden & Synchaeta spp. & 15 & Jun & 90 & Eriksson et al. (1977) \\
\hline Gullmar Fjord, Sweden & S. vorax & 85 & May & 90 & Hernroth (1983) \\
\hline Limfjord, Denmark & Synchaeta spp. & 100 & Jul & 110 & Blanner (1982) \\
\hline Tvarmine Storfjorden, Finland & Synchaeta spp. & 1200 & May & 10 & Kivi (1986) \\
\hline Seili, Finland & Synchaeta spp. & 100 & May & 150 & Vuorinen \& Ranta (1987) \\
\hline Comacchio, Italy & Synchaeta spp. & 10 & Mar & 71 & Ceccerelli \& Ferrari (1982) \\
\hline Rosefjord, Norway & Rotifers & 300 & Mar & 40 & Krause \& Kattner (1989) \\
\hline
\end{tabular}

for the spring and summer show a strong, yet unclear, relationship between microflagellate and rotifer populations. Rotifer concentrations were negatively related to microflagellate abundance but ER data for S. cecilia indicated a positive relationship between reproductive output and microflagellate concentration (Table 1). Inverse oscillations of rotifers and microflagellates, like those seen in the fall, were not apparent; while admitting that problems of sampling and variability in temporal lags can easily obscure such patterns, it was nonetheless surprising.

There are many possible explanations for a change in the abundance patterns of rotifers and microflagellates,

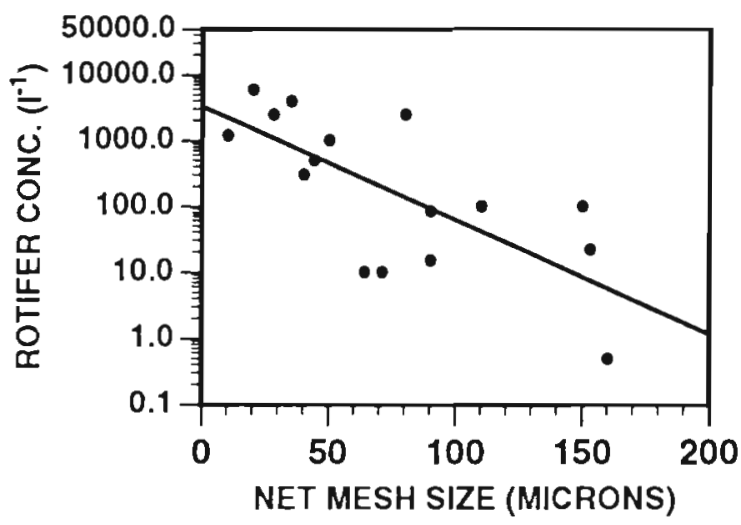

Fig. 6. Relationship between maximum rotifer concentration and sample concentration method from reports on estuarine waters. Data from Table 4, $\mathrm{r}=0.716, \mathrm{n}=16, \mathrm{p} \leq 0.01$ ranging from parasitism to changes in the composition of the microflagellate community, most of which can not be addressed with our data. However, we considered 2 obvious possibilities: a competitive relationship with herbivorous ciliates and control of rotifers by predation.

The rotifer-ciliate relationship

Planktonic rotifers and ciliates have been described as having food niches which overlap considerably (Wickham \& Gilbert 1991). Resource competition between the 2 groups could have complicated a rotifermicroflagellate relationship. Because ciliates can sustain growth at much lower food concentrations than rotifers (Heinbokel et al. 1988), ciliate numbers should increase and rotifers decrease when food levels are low. While field patterns are rarely unambiguous, no such relationship was obvious (Fig. 2). This observation, combined with the negative relationship between rotifers and ciliate concentrations (Fig. 2, Table 1), could tenuously support a hypothesis of interference competition. We have no data to directly evaluate this hypothesis but a review of the literature suggests that it is not an unreasonable possibility.

While rotifers are generally considered as grazers of small algal prey (Heinbokel et al. 1988), they are likely omnivorous to some extent as are most heterotrophic plankters. For example, one of the species encountered, Synchaeta vorax, has been reported to feed vora- 
ciously both on other rotifers (Rousselet 1904) and the bloom-forming alga Phaeocystis pouchetti (Hollowday 1949). Freshwater Synchaeta and Brachionus species can ingest relatively large $(\geq 20 \mu \mathrm{m})$ prey items (Gilbert \& Starkweather 1977, Gilbert \& Bogdan 1984) and feed on ciliates at high $\left(0.2\right.$ to $5.4 \mathrm{ml}$ cleared rotifer $\left.{ }^{-1} \mathrm{~d}^{-1}\right)$ rates (Gilbert \& Jack 1992). Furthermore, instances of brackish water Synchaeta spp. feeding on ciliates have been reported (Lindholm 1981, Arndt et al. 1990). Even the smallest Synchaeta species, S. cecilia (120 $\mu \mathrm{m}$ long), which dominated the Rhode River community, can feed on a dinoflagellate, Prorocentrum micans, $13 \times 47 \mu \mathrm{m}$, (Egloff 1988) which approaches the size of the most common herbivorous ciliate in the Rhode River (a 40 $\mu \mathrm{m}$ diameter Strombidium sp.).

Other workers have mentioned intriguing relationships between estuarine or marine rotifers and ciliates. Rotifers and tintinnid ciliates have been described as dominating 'in turn' in an Adriatic lagoon (Ceccherelli \& Ferrari 1982). Co-occurrence of rotifers and tintinnid ciliates has been noted in a fjord (Hernroth 1983) as well as Atlantic (Sanders 1987) and Pacific (Ambler et al. 1985) coast estuaries. Also, Eriksson et al. (1977) presented data from a Swedish fjord showing cooccurrence of Synchaeta spp. and tintinnids and an inverse relationship between aloricate ciliates and $S y n-$ chaeta spp. While some workers have hypothesized that rotifers compete with tintinnids in estuaries (Hernroth 1983, Sanders 1987, Heinbokel et al. 1988), it has been suggested that rotifers are the primary consumers of ciliates in a Baltic fjord (Gast 1985). The relationship between rotifers and ciliates in eutrophic estuaries and coastal waters needs further study, especially considering the implications of carnivory in low trophic levels for food chain efficiency (Stoecker \& Evans 1985).

\section{Predation by copepods and sea nettles}

Experiments were conducted with common cooccurring plankters to evaluate the possibility that predation may have had a significant impact on rotifers in the Rhode River. To our knowledge, these are the first estimates of grazing rates based on field experiments for either Acartia or Chrysaora quinquecirrha feeding on rotifers.

Estimates of clearance rates obtained in the copepod experiments correspond closely with previous laboratory studies with Acartia tonsa, the dominant copepod in the Rhode River during summer months (Allan et al. 1976). Synchaeta cecilia was cleared at ca $50 \mathrm{ml}$ copepod ${ }^{-1} \mathrm{~d}^{-1}$ (Table 2) in natural Rhode River plankton assemblages compared to 37 to $124 \mathrm{ml} \mathrm{copepod}^{-1}$ $\mathrm{d}^{-1}$ determined over a range of rotifer, ciliate and phytoplankton concentrations in experiments with cultured organisms (Stoecker \& Egloff 1987, Egloff 1988). Comparative data for the consumption of Brachionus plicatilis is lacking. However, laboratory studies of freshwater calanoid and cyclopoid copepods feeding on Brachionus and Synchaeta species at prey densities similar to those found in our field experiments (ca 500 ind $~^{-1}$ ) have given clearance estimates of 35 to $85 \mathrm{ml}$ copepod ${ }^{-1} \mathrm{~d}^{-1}$, with the higher rates associated with grazing on Synchaeta (Williamson 1983, Williamson \& Butler 1986), similar to the data for Rhode River organisms. Clearance rates for copepods determined on rotifer prey, like those estimated on ciliate prey (reviewed in Stoecker \& Capuzzo 1990, Gifford 1991), are high relative to rates determined on phytoplankton, indicating that despite the relative abundance of phytoplankton, carnivory is likely an important part of a copepod's diet (Stoecker \& Egloff 1987).

It is difficult to assess the role of copepod grazing on the population dynamics of rotifers in the Rhode River as contemporaneous data on rotifer and copepod abundances are not available. Data presented in Allan et al. (1976) showed low (about 0.5 ind. $1^{-1}$ ) average abundances of adult Acartia tonsa in the Rhode River yielding an estimate of only $2.5 \%$ of the water column cleared of rotifers per day, assuming a clearance rate of roughly $50 \mathrm{ml}$ copepod ${ }^{-1} \mathrm{~d}^{-1}$. However, concentrations vary over an order of magnitude from week to week (Allan et al. 1976) so that predation pressure may be sporadically as high as ca $15 \%$ of the water column cleared per day. It should be noted that these are only rough estimates since they are based on calculated instantaneous rates of copepod predation.

The clearance rates estimated for the sea nettle Chrysaora quinquecirrha (75 $\mathrm{mm}$ diameter) were quite variable, reflecting differences in estimates for individual animals. Averaging the rates for both Synchaeta and Brachionus as prey, over all the experiments (both grazing and egestion) yields an estimate of about 201 ind. ${ }^{-1} \mathrm{~h}^{-1}$. Other clearance rate data for the sea nettle are apparently unavailable. However, our estimate is within the wide range of data reported for other scyphomedusa species of roughly similar size, feeding on a comparably sized prey, at temperatures ranging from 20 to $30^{\circ} \mathrm{C}$. For example, Stoecker et al. (1987) working with $110 \mathrm{~mm}$ diameter Aurelia aurita determined clearance rates of 17 to $52 \mathrm{l}$ ind. ${ }^{-1} \mathrm{~d}^{-1}$ on prey ranging in size from euglenoid flagellates to copepod nauplii at temperatures of 19 to $20^{\circ} \mathrm{C}$. Larson (1991) estimated clearance rates for $55 \mathrm{~mm}$ bell height specimens of Stomolophus meleagris at 28 to $30^{\circ} \mathrm{C}$ to range from 4.8 to $172 \mathrm{l}_{\text {ind. }}{ }^{-1} \mathrm{~d}^{-1}$ on a variety of planktonic crustaceans. Larson (1991) also found a large amount of individual variability in clearance rates (i.e. $\mathrm{SD} \geq 50 \%$ of mean), aside from that expected due to differences in size and reproductive state. 
Based on our clearance rate estimate, sea nettle abundances would have to be quite high, relative to reported average concentrations of 5 to 10 ind. $\mathrm{m}^{-3}$ (Purcell et al. 1991), to have a substantial impact on the rotifer community. At an average abundance of 7 sea nettles $\mathrm{m}^{-3}$, sea nettles would clear only $15 \%$ of the water column of rotifers per day, using our average clearance rate of $20 \mathrm{l}$ sea nettle $\mathrm{d}^{-1}$. However, sea nettle distribution is extremely patchy and concentrations of 50 to 100 ind. $\mathrm{m}^{-2}$ were visible at the surface from the dock in August (pers, obs.).

The grazing experiments provided evidence that one possible fate of rotifers in the Rhode River is consumption by other metazoan plankters. However, the magnitude of the feeding rates estimated, combined with reasonable approximations of predator abundance, indicate that rotifers, although periodically subjected to large removal rates, probably are not usually predatorcontrolled. Similar conclusions regarding rotifer population dynamics in a Baltic inlet were reached by Arndt (1989).

\section{Production of Synchaeta cecilia}

Estimates of production were based on population growth rates from ER data for most of the dates. While the ER method compared favorably to rates based on measured increases in numbers, the estimates should be considered with certain caveats in mind. The ER method contains the assumption that all eggs reach adult size; if any egg or juvenile mortality occurs production will be overestimated. This is a potential source of error for which we have no data. On many dates, ER was low (Fig. 3) and very large sample sizes are needed for estimates of even modest precision under such circumstances (Demott 1980). Calculations were based on the assumptions that there was no diel cycle of reproduction or significant spatial heterogeneity in $E_{\text {; }}$ violations of these assumptions can lead to serious errors in estimating population dynamics (Magnien \&
Gilbert 1983). There are few data on diel periodicities in estuarine rotifers aside from a recent report of a diel rhythm of feeding in an estuarine population of Brachionus plicatilis (Arndt \& Heerkloss 1989). On the other hand, limited data (not shown) from transect samples indicated that spatial differences appeared to be minor. Unless these possible sources of error led to consistent overestimation, the production of Synchaeta cecilia in the Rhode River is large, and of a magnitude similar to copepods and ciliates in the Chesapeake Bay and its tributaries (Table 5). The average calculated production for the Rhode River is an order of magnitude greater than that of copepods, as Allan et al. (1976) had speculated it might be.

The estimates for rotifer production in other brackish waters suggests that the magnitude of rotifer production in the Rhode River is probably not unusual. Heinbokel et al. (1988), based on ER data, calculated Synchaeta cecilia production during March in the Potomac River estuary to range from 0.97 to $8.27 \mu \mathrm{g} \mathrm{C} \mathrm{l}^{-1} \mathrm{~d}^{-1}$ compared to $18.3 \mu \mathrm{g} \mathrm{Cl}^{-1} \mathrm{~d}^{-1}$ in the Rhode River (Table 5). Hernroth (1983) estimated peak Synchaeta spp. production for the Gullmar Fjord to be about $1.5 \mu \mathrm{g} \mathrm{C}$ $\mathrm{I}^{-1} \mathrm{~d}^{-1}$ during the spring phytoplankton bloom, based on abundance data from samples collected with a large mesh $(90 \mu \mathrm{m})$ plankton net which he noted likely missed small rotifers.

The pattern of rotifer production in the Rhode River, characterized by large temporal variability and a weak relation to microflagellate concentration, is difficult to relate to other estuarine systems as very few comparative data exist. However, a short-term study ( $\leq 2 \mathrm{wk}$ ) of rotifer reproduction in the Potomac River estuary, Maryland, USA (Tyler \& Heinbokel 1985) noted the lack of a simple correlation between rotifer ER and apparent food levels, whether considered as separate phytoplankton taxa or as chl a. Later, Heinbokel et al. (1988) described a saturating relationship beween ER and chl a over a medium temporal and spatial scale, i.e. using data averaged over the water column from several Potomac River stations along a salinity gradient

Table 5. Estimates of average production rates $\left(\mu \mathrm{g} \mathrm{C}^{-1} \mathrm{~d}^{-1}\right)$ of various zooplankton groups in the Cheasapeake Bay and its subestuaries. Primary production is high in these systems: e.g. production in the Rhode River on an annual basis averages $1250 \mu \mathrm{g}$ $\mathrm{Cl}^{-1} \mathrm{~d}^{-1}$ (Correll 1978); in the Patuxent River during the summer, ca $600 \mu \mathrm{g} \mathrm{C} \mathrm{l}^{-1} \mathrm{~d}^{-1}$ (Heinle 1966); and euphotic zone primary production in the mesohaline Chesapeake Bay ranges from ca 200 to $1000 \mu \mathrm{C} \mathrm{l}^{-1} \mathrm{~d}^{-1}$ during spring and summer (Sellner 1987)

\begin{tabular}{|c|c|c|c|c|}
\hline Organism & Location & Season & Production & Source \\
\hline S. cecilia & Rhode River & Spring - summer & 18.3 & This study \\
\hline S. cecilia & Potomac River & Spring & 3.5 & Heinbokel (1988) \\
\hline Acartia tonsa & Rhode River & Summer & 1.4 & Allan et al. $(1976)$ \\
\hline Acartia tonsa & Patuxent River & Summer & 27.8 & Heinle (1966) \\
\hline Copepods & Chesapeake Bay & Annual & 33 & Storms (1975) \\
\hline Ciliates & Chesapeake Bay & Spring - summer & 13.5 & Dolan (1988) \\
\hline
\end{tabular}


sampled over several days. A similar relationship between rotifer production and microflagellate concentrations in the Rhode River may have been apparent had we integrated values over various time periods.

Rotifers have received little attention in studies of estuarine and marine plankton, and while this can be understood as due to their limited distribution and under-representation in net samples (Heinbokel et al. 1988), it is nonetheless a possibly serious omission. In the Rhode River at least, rotifers are numerous, with production rates comparable to copepods and ciliates. Although it is not clear what factors, if any, consistently regulate rotifer populations in the Rhode River, they appear to interact competitively with herbivorous ciliates and serve as food for other planktonic metazoans. It is quite possible that rotifers are equally important in other estuarine systems but have not been adequately sampled.

Acknowledgements. This work was supported by the Smithsonian Office of Fellowships and Grants. Paul Turner of the National Museum of Natural History provided a valuable and enthusiastic introduction to rotifer taxonomy. The manuscript was greatly improved by comments from D. W. Coats, J. J. Gilbert, R. S. Stemberger, D. K. Stoecker and 2 anonymous reviewers.

\section{LITERATURE CITED}

Allan, J. D. (1976). Life history patterns in zooplankton. Am. Nat. 110: 165-180

Allan, J. D., Kinsey, T G., James, M. C. (1976). Abundance and production of copepods in the Rhode River subestuary of Chesapeake Bay. Chesapeake Sci. 17: 86-89

Ambler, J. W., Cloern, J. E., Hutchinson, A. (1985). Seasonal cycles of zooplankton from San Francisco Bay. Hydrobiologia 129: 177-197

Arndt, H. (1989). Zooplankton production and its consumption by planktivores in a Baltic inlet. Proc. 21st Eur. Mar. Biol. Symp. Institute of Oceanology, Polish Academy of Sciences, Polish National Committee on Oceanic Research, p. 205-214

Arndt, H., Heerkloss, R. (1989). Diurnal variation in feeding and assimilation rates of planktonic rotifers and its possible ecological significance. Int. Revue ges. Hydrobiol. 74: 261-272

Arndt, H., Schröder, C., Schnese, W. (1990). Rotifers of the genus Synchaeta - an important component of the zooplankton in the coastal waters of the southern Baltic. Limnologica 21: 233-235

Beauchamp, P. de (1907). Description de trois rotifères nouveaux de la faune française. Bull. Soc. Zool. France 32: $148-157$

Berzins, B. (1952). Rotaria 1, order: Monogonata, suborder: Ploima, family: Synchaetidae, genus: Synchaeta. In: Frazer, J. H., Hansen, V. Kr. (eds.) Fiches d'indentification $\mathrm{du}$ zooplankton. Conseil Permanent International Pour L'Exploration De La Mer, Charlottenlund slot, Denmark, Zooplankton sheet 84

Björklund, B. G. (1972). Taxonomic and ecological studies of species of Notholca (rotatoria) found in sea- and brackish water, with description of a new species. Sarsia 51: 25-66
Blackbourn, D. J. (1974). The feeding biology of tintinnid protozoa and some other inshore microzooplankton. Ph.D. thesis, University of British Columbia, Vancouver

Blanner, P. (1982). Composition and seasonal variation of the zooplankton in the Limfjord (Denmark) during 1973-1974. Ophelia 21: $1-40$

Brownlee, D. C., Jacobs, F. (1987). Mesozooplankton and microzooplankton in the Chesapeake Bay. In: Majumadar, S. K., Hall, L. W. Jr, Austin, H. M. (eds.) Contaminant problems and management of living Chesapeake Bay resources. Phil. Acad. Sci., Philadelphia, p. 217-269

Ceccherelli, V U., Ferrari, I. (1982). Annual and seasonal variation of zooplankton in a shallow-water lagoon system, the Valli of Comaacchio. Estuar. coast. Shelf Sci. 14:337-350

Correll, D. L. (1978). Estuarine productivity. Bioscience 28: $645-650$

Correll, D. L. (1981). Eutrophication trends in the water quality of the Rhode River (1971-1978). In: Neilson, B. J., Cronin, L. E. (eds.) Estuaries and nutrients. Humana Press, Clifton, NJ, p. $425-435$

Cory, R. L., Dressler, P. V. (1981). Diel oxygen variations in the Rhode River estuary, Maryland 1970-1978. U.S.G.S. Wat. Res. Inves. 8: 1-10

Demott, W. R. (1980). An analysis of the precision of birth and death rate estimates for egg-bearing zooplankters. In: Kerfoot, W. C. (ed.) Evolution and ecology of zooplankton communities. University Press of New England, Hanover, p. $337-345$

Dewey, J. M. (1976). Rates of feeding, respiration, and growth of the rotifer Brachionus plicatilis and the dinoflagellate Noctiluca miliaris in the laboratory. Ph.D. thesis, University of Washington, Seattle

Dolan, J. R. (1988). The ecology of ciliate microzooplankton in the Chesapeake Bay. Ph.D. thesis, University of Maryland, College Park

Dolan, J. R. (1991). Guilds of ciliate microzooplankton in the Chesapeake Bay. Estuar. coast. Shelf Sci. 33: 137-152

Dolan, J. R., Gallegos, C. L. (1991). Trophic coupling of rotifers, microflagellates, and bacteria during fall months in the Rhode River estuary. Mar. Ecol. Prog. Ser. 77: 147-156

Doohan, M. (1973). An energy budget for adult Brachionus plicatilis Müller (Rotatoria). Oecologia 13: 351-362

Droop, M. R., Scott, J. M. (1978). Steady-state energetics of a planktonic herbivore. J. mar. biol. Ass. U.K. 58: 749-772

Edmondson, W. T. (1960). Reproductive rates of rotifers in natural populations. Mem. Ist. Ital. Idrobiol. 12: 21-77

Edmondson, W. T. (1965). Reproductive rate of planktonic rotifers as related to food and temperature in nature. Ecol. Monogr. 35: 61-111

Egloff, D. A. (1988). Food and growth relations of the marine microzooplankter Synchaeta cecilia (Rotifera). Hydrobiologia 157: 129-141

Eriksson, S. (1973). Preliminary zooplankton investigations in the Öregrund Archipelago (southwestern Bothnian Sea) during the summer 1970. Zoon 1: 95-111

Eriksson, S., Sellei, C., Wallström, K. (1977). The structure of the plankton community of the Öregrundsgrepen (southwest Bothnian Sea). Helgoländer wiss. Meeresunters. 30: $582-597$

Frost, B. W. (1972). Effects of size and concentration of food particles on the feeding behaviour of the marine planktonic copepod Calanus pacificus. Limnol. Oceanogr. 17: 805-815

Gallegos, C. L., Jordan, T. E., Correll, D. L. (1992). Event-scale response of phytoplankton to watershed inputs in a subestuary: timing, magnitude and location of blooms. Limnol. Oceanogr. 37: in press

Gallegos, C. L. (1989). Microzooplankton grazing on phyto- 
plankton in the Rhode River, Maryland: nonlinear feeding kinetics. Mar. Ecol. Prog. Ser 57: 23-33

Gast, V. (1985). Bacteria as a food source for microzooplankton in the Schlei Fjord and Baltic Sea with special reference to ciliates. Mar. Ecol. Prog. Ser 22: 107-120

Gifford, D. J. (1991). The protozoa-metazoan trophic link in pelagic ecosystems. J. Protozool. 38: 81-86

Gilbert, J. J., Bogdan, K. G. (1984). Rotifer grazing: in situ studies on selectivity and rates. In: Meyers, D. G., Strickler, J. R. (eds.) Trophic interactions within aquatic ecosystems, AAAS selected symposium 85. Amer. Assoc. Advanc. Sci., Washington DC, p. 97-133

Gilbert, J. J., Jack, J. D. (1992). Rotifers as predators on small ciliates. Hydrobiologia (in press)

Gilbert, J. J., Starkweather, P. L. (1977). Feeding in the rotifer Brachionus calyciflorus 1. Regulatory mechanisms. Oecologia 28: 125-131

Hass, L. W. (1982). Improved epifluorescent microscopic technique for observing planktonic micro-organisms. Annls Inst. océanogr., Paris 58: 285-295

Heinbokel, J. F., Coats, D. W., Henderson, K. W., Tyler, M. A. (1988). Reproduction rates and secondary production of three species of the rotifer genus Synchaeta in the estuarine Potomac River. J. Plankton Res. 10: 659-674

Heinle, D. R. (1966). Production of a calanoid copepod, Acartia tonsa in the Patuxent River estuary. Chesapeake Sci. 7 : $59-74$

Hernroth, L. (1983). Marine pelagic rotifers and tintinnids important trophic links in the spring plankton community of the Gullmar Fjord, Sweden. J. Plankton Res. 5: 835-846

Hollowday, E. D. (1949). Preliminary report on the Plymouth marine and brackish-water rotifera. J. mar. biol. Ass. U.K 28: 239-253

Hulsizer, E. E. (1976). Zooplankton of lower Narragansett Bay Chesapeake Sci. 17: 260-270

Johansson, S. (1983). Annual dynamics and production of rotifers in an eutrophication gradient in the Baltic Sea Hydrobiologia 104: 335-340

Jordan, T. E., Correll, D. L., Miklas, J., Weller, D. E. (1991) Nutrients and chlorophyll at the interface of a watershed and an estuary. Limnol. Oceanogr. 36: 251-267

Kivi, K. (1986). Annual succession of pelagic protozoans and rotifers in the Tvärminne Storfjärden, SW coast of Finland Ophelia suppl. 4: 101-110

Krause, M., Kattner, G. (1989). The influence of water exchange on zooplankton dynamics and species development in a south Norwegian fjord. J. Plankton Res. 11: 85-103

Larson, R. J. (1991). Diet, prey selection and daily ration of Stomolophus maleagris, a filter-feeding scyphomedusa from NE Gulf of Mexico. Estuar. coast. Shelf Sci. 32: 511-525

Likens, G. E., Gilbert, J. J. (1970). Notes on the quantitative sampling of natural populations of planktonic rotifers. Limnol. Oceanogr. 15: 816-820

Lindholm, T. (1981). On the ecology of Mesodinium rubrum (Lohmann) (Ciliata) in a stagnant brackish water basin on Aland. SW Finland. Kieler Meeresforsch. Sonderh. 5: $117-123$

Magnien, R. E., Gilbert, J. J. (1983). Diel cycles of reproduction and vertical migration in the rotifer Keratella crassa and their influence on the estimation of population dynamics. Limnol. Oceanogr. 28: 957-969

Orcutt, J. D., Pace, M. L. (1984). Seasonal dynamics of rotifer and crustacean zooplankton populations in a eutrophic, monomictic lake with a note on rotifer sampling techniques. Hydrobiologia 119: 73-80

Paloheimo, J. (1974). Calculation of instantaneous birth rate. Limnol. Oceanogr. 19: 692-694
Pennak, R. W. (1978). Fresh-water invertebrates of the United States, 2nd edn. J. Wiley and Sons, New York, p. 157

Pilarska, J. (1977). Eco-physiological studies on Brachionus rubens Ehrbg. (Rotatoria) 1. Food selectivity and feeding rate. Pol. Arch. Hydrobiol. 24: 319-328

Pourriot, R. (1965). Recherches sur l'écologie des rotifères. Vie Milieu suppl. 21: 179

Pourriot, R. (1977). Food and feeding habits of Rotifera. Arch. Hydrobiol. Beih. Ergebn. Limnol. 8: 243-260

Pourriot, R., Rougier, C. (1979). Influence conjuguées du groupment et de la qualité de la nourriture sur la reproduction de Brachionus plicatilis O.F. Müller (Rotifère). Neth. J. Zool. 29: 242-264

Purcell, J. E., Cresswell, F. P., Cargo, D. G., Kennedy, V S. (1991). Differential ingestion and digestion of bivalve larvae by the scyphozoan Chrysaora quinquecirrha and the ctenophore Mnemiopsis leidyi. Biol. Bull. 180: 103-111

Remane, A. (1929). Rotatoria. Tierwelt der Nord- und Ostsee. $7(14): 1-156$

Rousselet, C. F. (1902). The genus Synchaeta: a monographic study with descriptions of five new species. J. R. microsc. Soc. 1902: 269-290, 393-411

Rousselet, C. F. (1909). On Synchaeta fennica sp. n. and remarks on the resting egg of Synchaeta pectinata. J. R. microsc. Soc. 1909: 170-173

Ruttner-Kolisko, A. (1974). Plankton rotifers, biology and taxonomy. E. Schweizerbart'sche Verlagsbuchhandlung (Nägele u. Obermiller), Stuttgart

Sanders, R. W (1987). Tintinnids and other microzooplankton - seasonal distributions and relationships to resources and hydrography in a Maine estuary. J. Plankton Res. 9: 65-77

Scmid-Araya, J. M. (1991). The effect of food concentration on the life histories of Brachionus plicatilis (O.F.M.) and Encentrum linnhei Scott. Arch. Hydrobiol. 121: 87-102

Sellner, K. G. (1987). Phytoplankton in Chesapeake Bay: role in carbon, oxygen and nutrient dynamics. In: Majumadar, S. K., Hall, L. W. Jr, Austin, H. M. (eds.) Contaminant problems and management of living Chesapeake Bay resources. Phil. Acad. Sci., Philadelphia, p. 134-157

Sellner, K. G., Lacouture, R. V., Cibik, S. J., Brindley, A., Brownlee, S. G. (1991). Importance of a winter dinoflagellate-microflagellate bloom in the Patuxent River estuary. Estuar, coast. Shelf Sci. 32: 27-42

Smith, J. C. (1904). Synchaeta bicornis: a new rotifer from the brackish waters of Lake Pontchartrain, Lousiana. Trans. Amer. Micros. Soc. 25: 121-126

Stemberger, R. S., Gilbert, J. J. (1985). Body size, food concentration, and population growth in planktonic rotifers. Ecology 66: 1151-1159

Stoecker, D. K., Evans, G. T (1985). The effects of herbivory and carnivory in a microplankton food web. Mar. Ecol. Prog. Ser. 25: 159-167

Stoecker, D. K., Egloff, D. A. (1987). Predation by Acartia tonsa on planktonic ciliates and rotifers. J. exp. mar. Biol. Ecol. 110: 53-68

Stoecker, D. K., Michaels, A. E., Davis, L. H. (1987). Grazing by the jellyfish, Aurelia aurita, on microzooplankton. J. Plankton Res. 9: 901-915

Stoecker, D. K., Capuzzo, J. M. (1990). Predation on protozoa: its importance to zooplankton. J. Plankton Res. 12: 891-908

Storms, S. E. (1975). Selective feeding, ingestion and assimilation rates, and distribution of the copepod Acartia in Chesapeake Bay. Ph.D. thesis, The Johns Hopkins University, Baltimore

Tyler, M. A., Heinbokel, J. F. (1985). Cycles of red water and encystment of Gymnodinium pseudopalustre in the 
Chesapeake Bay: effects of hydrography and grazing. In: Anderson, D. A., Baden, D. (eds.) Toxic dinoflagellates. Elsevier, New York, p. 213-218

Voigt, M., Koste, W. (1978). Rotatoria, Die Rädertiere Mitteleuropas. Gebrüder Borntraeger, Berlin

Vuorinen, I., Ranta, E. (1987). Dynamics of marine mesozooplankton at Seili, northern Baltic Sea, in 1967-1975. Ophelia 28: $31-48$

Walker, K. F. (1981). A synopsis of ecological information on the saline lake rotifer Brachionus plicatilis Müller 1786. Hydrobiologia 81: 159-167

This article was presented by D. K. Stoeker, Cambridge, Maryland, USA
Wickham, S. A., Gilbert, J. J. (1991). Relative vulnerabilities of natural rotifer and ciliate communities to cladocerans: laboratory and field experiments. Freshwat. Biol. 26: 77-86 Williamson, C. E. (1983). Invertebrate predation on planktonic rotifers. Hydrobiologia 104: 385-396

Williamson, C. E., Butler, M. N. (1986). Predation on rotifers by the suspension-feeding calanoid copepod Diaptomus pallidus. Limnol. Oceanogr. 31: 393-402

Yúfera, M., Pascual, E. (1985). Effects of algal food concentration on feeding and ingestion rates of Brachionus plicatilis in mass culture. Hydrobiologia 122: 181-187

Manuscript first received: January, 7, 1992

Revised version accepted: June 23, 1992 